\title{
Antioxidative Activity of Peptides Prepared from Okara Protein
}

\author{
Atsushi YoKOMIZO, ${ }^{1}$ Yoko TAKENAKA ${ }^{2}$ and Tetsuo TAKENAKA ${ }^{1}$ \\ ${ }^{I}$ T\&T Food Institute, 555-20, Aina, Atsugi-shi, Kanagawa 243-0038, Japan \\ ${ }^{2}$ Faculty of Agriculture, Tamagawa University, 6-1-1 Tamagawa-Gakuen, Machidashi, Tokyo 194-8610, Japan
}

Received June 6, 2002; Accepted September 5, 2002

\begin{abstract}
Protease hydrolyses of an Okara protein yielded antioxidative activity against the peroxidation of linoleic acid in an aqueous system at pH 7.0. Four antioxidative peptides were isolated from the hydrolysate prepared with Protease $\mathrm{N}$ by size exclusion chromatography and reversed-phase HPLC. The peptides were composed of two and three amino acid residues, including aromatic amino acid at the $\mathrm{C}$ terminal end. Their amino acid sequences were determined to be Ala-Tyr, Gly-Tyr-Tyr, Ala-Asp-Phe, and Ser-Asp-Phe, respectively. The antioxidative activity of Gly-Tyr-Tyr is nearly equal to that of carnosine.
\end{abstract}

Keywords: antioxidative activity, amino acid, peptide, hydrolysate, Okara

In the manufacturing of soymilk and tofu, the soymilk residue, Okara, is produced as a by-product with little market value. However, Okara still contains about $25 \%$ protein (dry basis) with high nutritive quality. Studies on the utility of Okara (Takenaka et al., 1996; Miyamura et al., 1998; Tamura \& Takenaka, 1999) have been done, but utilization of the substance is still in the developmental stage. Antioxidative activity has recently been detected in peptides from the proteolytic hydrolysis of many food proteins (Suetsuna et al., 2000; Chen et al., 1995). In this study, we examined the antioxidative effects of enzymatic hydrolysates of Okara protein with seven different proteases.

\section{Materials and Methods}

Materials The Okara protein was prepared using the method of Yamauchi et al. (1984). Proteases were purchased from Amano Enzyme Co., Ltd (Nagoya, Japan): Protease A from Aspergillus oryzae, $10,000 \mathrm{u} / \mathrm{g}, \mathrm{pH} 7.0 ;$ Protease $\mathrm{M}$ from Aspergillus oryzae, 150,000 u/g, pH 7.0; Protease N from Bacillus subtilus, 30,000 u/g, $\mathrm{pH} 7.0$; Protease $\mathrm{P}$ from Aspergillus melleus, 30,000 u/g, pH 8.0; Protease S from Bacillus sp. 10,000 u/g, pH 7.0; Prolezer from Bacillus subtilus 10,000 u/g, pH 9.0; and Papain W-40 from Carica pancreas, $400 \mathrm{u} / \mathrm{g}$, pH 8.0.

Preparation of the Okara protein hydrolysate Okara protein $(10 \mathrm{~g})$ was dissolved in $200 \mathrm{ml}$ of distilled water, and heated at $100^{\circ} \mathrm{C}$ for $10 \mathrm{~min}$. Protease $(0.2 \mathrm{~g})$ was added to the protein solution after the $\mathrm{pH}$ was properly adjusted. Enzymatic hydrolysis was performed under optimum $\mathrm{pH}$ conditions as the manufacturer recommended. After digestion, hydrolysates were heated in boiling water for $5 \mathrm{~min}$ to inactivate proteases, then neutralized and centrifuged $(20,000 \times g$ for $10 \mathrm{~min})$. The supernatants were lyophilized and stored in $4^{\circ} \mathrm{C}$ until use.

Measurement of antioxidative activity Linoleic acid (10 $\mathrm{mg}$ ) in $0.5 \mathrm{ml}$ of ethanol, samples in $4.0 \mathrm{ml}$ of $0.2 \mathrm{M}$ phosphate

\footnotetext{
* To whom correspondence should be addressed.
}

E-mail: takenaka@agr.tamagawa.ac.jp buffer (pH 7.0), and $0.15 \mathrm{ml}$ of $20 \mathrm{mM}$ 2,2'-azobis(2-amidinopropane) dihydrochloride (AAPH) were placed in a vial, which was then sealed tightly and kept at $50^{\circ} \mathrm{C}$ in the dark. At regular intervals, an aliquot of the reaction mixture was withdrawn for measurement of the oxidation using the ferric thiocyanate method (Mitsuda et al., 1966). The time taken to attain an absorbance of 0.3 was defined as the induction period. The relative antioxidative activity was calculated by dividing the induction period of test samples by that of the control.

Isolation of antioxidative peptides The hydrolysate $(0.2 \mathrm{~g})$ was dissolved in $1 \mathrm{ml}$ of $50 \mathrm{~mm}$ acetic acid and fractionated by size exclusion chromatography on a Sephadex G-25 column $(16 \times 900 \mathrm{~mm}$, Pharmacia Co.) equilibrated and eluted with the same solvent. Fractions of $4 \mathrm{ml}$ were collected at a flow rate of $0.8 \mathrm{ml} / \mathrm{min}$. The absorbance at $280 \mathrm{~nm}$ and antioxidative activity of all fractions were measured. Tyrosin (Mw, 181), maltohexaose (Mw, 990), and bacitracin (Mw, 1422) were used as the molecular markers. The yield of antioxidative fraction estimated by the $o$-phthalaldehyde method (Church et al., 1983) was $13 \mathrm{mg}$ from $1 \mathrm{~g}$ of Okara protein. The antioxidative fraction was dissolved in distilled water and separated by reversed-phase HPLC on a TSKgel ODS $120 \mathrm{~T}$ column $(4.6 \times 250 \mathrm{~mm}$, TOSOH Co., Tokyo using a linear gradient of acetonitrile (0-50\% in $60 \mathrm{~min})$ containing $0.1 \%$ trifluoroacetic acid (TFA). Separations were accomplished at $35^{\circ} \mathrm{C}$ and a flow rate of $1.0 \mathrm{ml} / \mathrm{min}$. The elution peaks were monitored at $230 \mathrm{~nm}$, and their antioxidative activities were measured using $1 / 50$ of each sample. The active peaks were collected and lyophilized.

Amino acid analysis The peptides were hydrolyzed with $6 \mathrm{~N} \mathrm{HCl}$ at $110^{\circ} \mathrm{C}$ for $24 \mathrm{~h}$. Amino acid composition was analyzed by an automated amino acid analyzer (JCL-500V; JEOL, Tokyo).

Sequence analysis Amino acid sequences of peptides were analyzed using a Procise 494 cLC protein sequencer (PERKIN ELMER, Applied Biosystems). 


\section{Results and Discussion}

The antioxidative activity of the hydrolysates with seven different proteases was measured (Fig. 1); in each experiment, the activity of all hydrolysates increased with hydrolysis. The antioxidative activity of hydrolysates treated with Protease A, N, M and $P$, reached maximum at 3-6 h of hydrolysis and decreased slight-

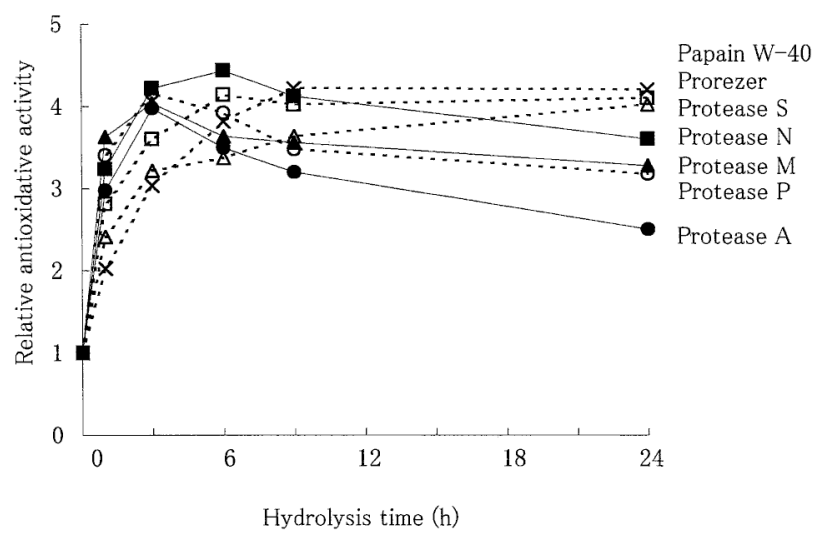

Fig. 1. Antioxidative activity of Okara protein hydrolysated with seven proteases. The antioxidative activity of each hydrolysate was measured by the ferric thiocyanate method. Ten milligrams of sample was used for the

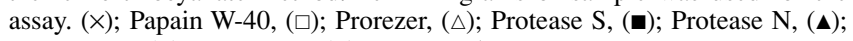
Protease M, (०); Protease P, (•); Protease A.

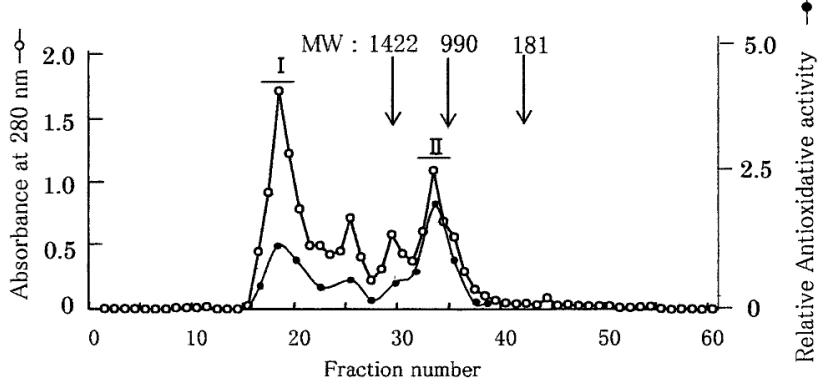

Fig. 2. Elution profile and antioxidative activity of Okara protein hydrolysated with Protease $\mathrm{N}$ for $6 \mathrm{~h}$ by Sephadex G-25. One milliliter of each fraction $(5 \mathrm{ml})$ was used to determine the the antioxidative Activity. (O); Absorbance at $280 \mathrm{~nm},(\bullet)$; Relative antioxidative activity

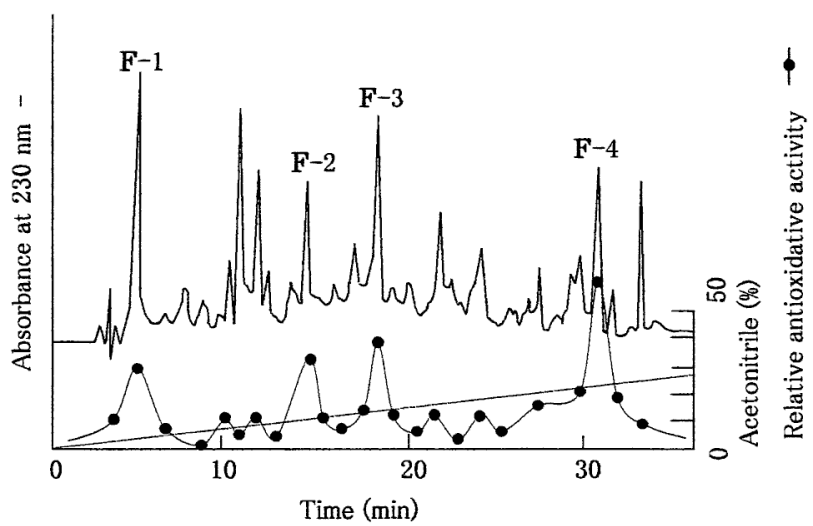

Fig. 3. Elution profile and antioxidative activity of F-II separated by HPLC. One-fiftieth of each fraction was used to determine the antioxidative activity $(\bullet)$. ly after $8 \mathrm{~h}$, while the activities of hydrolysates treated with the proteases Protease S, Prorezer, and Papain W increased rapidly for $8 \mathrm{~h}$ and reached a plateau.

This results indicated that antioxidative activity of the hydrolysates was inherent to their characteristic amino acid sequences of peptides depending on the protease specificities. The hydrolysate with Protease $\mathrm{N}$ for $6 \mathrm{~h}$ showed the highest antioxidative activity.

To characterize the antioxidative peptides derived from Okara protein hydrolyzed with Protease $\mathrm{N}$ for $6 \mathrm{~h}$, the hydrolysate was separated by size exclusion chromatography on Sephadex G-25 (Fig. 2). Fraction II showed the strongest antioxidative activity, and was estimated to be about $1000 \mathrm{Da}$ by molecular weight standard. This fraction was subjected to HPLC to isolate the antioxidative peptide, and fractionated to F-1, F-2, F-3, and F-4 (Fig. 3). From the hydrolysate with Protease N, four antioxidative peptides were finally isolated; their sequences were in good agreement with their amino acid compositions. The amino acid se-

Table 1. Amino acid sequences of antioxidative peptides isolated from the hydrolysate of Okara protein with Protease $\mathrm{N}$ for $6 \mathrm{~h}$.

\begin{tabular}{lc}
\hline Peptide & Amino acid sequences \\
\hline F-1 & Ala-Tyr \\
F-2 & Gly-Tyr-Tyr \\
F-3 & Ala-Asp-Phe \\
F-4 & Ser-Asp-Phe \\
\hline
\end{tabular}

Table 2. Arnino acid composition of antioxidative peptides derived from the hydrolysis of Okara protein.

\begin{tabular}{lcccc}
\hline Amino acid & F-1 & F-2 & F-3 & F-4 \\
& \multicolumn{2}{c}{$(\mathrm{nmol})$} \\
\hline $\begin{array}{l}\text { Asp } \\
\text { Ser }\end{array}$ & & & $1.1(1)$ & $1.0(1)$ \\
Gly & & & & $0.9(1)$ \\
Ala & $1.2(1)$ & & & \\
Tyr & $1.1(1)$ & $2.0(2)$ & & \\
Phe & & & $1.0(1)$ & $1.0(1)$ \\
\hline Total & 2 & 3 & 3 & 3 \\
\hline
\end{tabular}

Numbers in parenthesis deduced from the sequences.

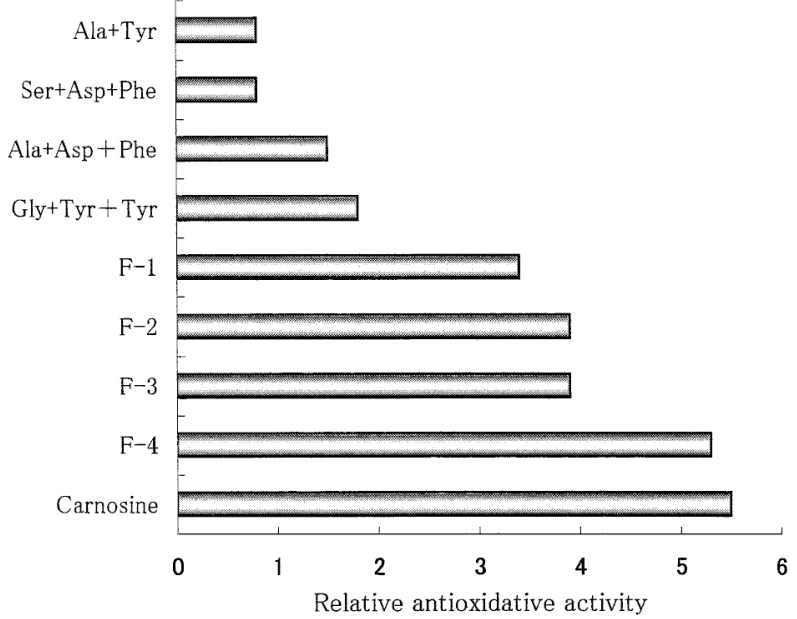

Fig. 4. Antioxidative activities of various amino acids mixtures and peptides. The sample concentration was performed with $10 \mu \mathrm{M}$. Data represent the mean of three replications. 
quences and amino acid composition of these peptides are shown in Tables 1 and 2. All peptides were di- or tripeptide which were lower in molecular weight than the other antioxidative peptides reported previously (Kudoh et al., 2001; Kim et al., 2001; Chen et al., 1995), and each had an aromatic amino acid at the C-terminal end.

Since the antioxidative effects of some amino acids have been shown (Karel et al., 1966), we compared the antioxidative activity of the four peptides with those of each constituent amino acid. When these amino acids were mixed at the same concentration as the peptides, the antioxidative activity of the amino acid mixture of each corresponding peptide was much less than that of each peptide itself (Fig. 4). The antioxidative activity of Gly-TyrTyr was nearly that of carnosine, but those of Ala-Asp-Phe and Ser-Asp-Phe and Ala-Tyr were less than that of carnosine. Thus, it was obvious that characteristic amino acid sequences of a peptide are important for the antioxidative activity. The isolation of other antioxidative peptides from hydrolysates is now being done to determine the relationship between amino acid sequence and activity.

\section{References}

Chen, H.M., Muramoto, K. and Yamauchi, F. (1995). Structural analysis of antioxidative peptides from soybean $\beta$-conglycinin. J. Agric. Food Chem., 43, 574-578.

Church, F.C., Swaisgood, H.F., Porter, D.H. and Catignani, G.L. (1983). Stectrophotometric assay using o-phthaldialdehyde for determination of proteolysis in milk and isolated with milk proteins.
J. Dairy Sci., 66, 1219-1227.

Karel, M., Tannenbaum, S.R., Wallace, D.H. and Maloney, H. (1966). Autoxidation of methyl linoleate in freeze-dried model systems. Effects of added amino acids. J. Food Sci., 31, 892-896.

Kim, S.K., Kim, Y.T., Byun, H.G., Nam, K.S., Joo, D.S and Hahidi, F. (2001). Isolation and characterization of antioxidative peptides from gelatin hydrolysate of Alaska pollack skin. J. Agric. Food Chem., 49, 1984-1989.

Kudoh, Y., Matsuda, S., Igoshi, K. and Oki, T. (2001). Antioxidative peptide from milk fermented with Lactobacillus delbrueckii subsp. Bulgaricus IFO13953. Nippon Shokuhin Kagaku Kogaku Kaishi, 48, 44-50 (in Japanese).

Mitsuda, H., Yasumoto, K. and Iwami, K. (1966). Antioxidative action of indole compounds during the autoxidation of linoleic acid. Eiyo To Syokuryo, 19, 210-214 (in Japanese).

Miyamura, H., Takenaka, Y. and Takenaka, T. (1998). Fibrinolytic activity of okara fermented by Bacillus subtilis. Nippon Shokuhin Kagaku Kogaku Kaishi, 45, 100-107 (in Japanese).

Suetsuna, K., Ukeda, H. and Ochi, H. (2000). Isolation and characterization of free radical scavenging activities peptides derived from casein. J. Nutr. Biochem., 11, 128-131.

Takenaka, T., Tamura, Y. and Takenaka, Y. (1996). Water soluble antioxidant in supernatant fraction of okara, a by-product of tofu manufacturing. Food Sci. Technol., Int., 2, 19-23.

Tamura, Y. and Takenaka, T. (1999). Antioxidative activity of water soluble extracts from okara fermented with Bacillus natto and Rizopus oligosporus. Nippon Shokuhin Kagaku Kogaku Kaishi, 46, 561569 (in Japanese).

Yamauchi, F., Sato, K. and Yamagishi, T. (1984). Isolation and partial characterization of a salt extractable globulin from soybean seeds. Agric. Biol. Chem., 48, 645-650. 